\title{
PHYTOCHEMICAL SCREENING AND ANTIMICROBIAL ACTIVITY OF FALSE YAM (ICACINA OLIVIFORMIS) EXTRACTS ON MICROBES
}

\author{
R. Seidu*, A. K. Quainoo, S. J. Cobbina And L. Quansah \\ (R. S., A. K. $Q$ \& L. Q.: Department of Biotechnology, University for De- \\ velopment Studies, Tamale, Ghana, S. J. C.: Department of Environment \\ and Sustainability, University for Development Studies, Tamale, Ghana). \\ Corresponding author's email: ramatuseidu77@gmail.com
}

\begin{abstract}
This study compares the phytochemicals and antimicrobial activity of Icacina oliviformis tuber and seed extracts on Staphylococcus aureus, Streptococcus pyogenes, Pseudomonas aeruginosa, Escherichia coli and Candida albicans. False yam tubers were washed and peeled and the mesocarp removed to obtain the seeds. Methanol was used to obtain tuber and seed extracts of the false yam, after they were pulverized. Phytochemical screening showed the presence of tannins, saponins, alkaloids and glycosides in both extracts but the proportion of tannins and alkaloids were relatively higher in false yam seed extract than tuber extract. Antimicrobial assay showed that both extracts had antimicrobial activity justifying its use in the treatment of diseases in Northern Ghana. False yam seed extract had a relatively higher antimicrobial activity than tuber extract. The least minimum inhibition concentration recorded was $1.56 \mathrm{mg} /$ $\mathrm{ml}$ for false yam seed on Gram-positive bacteria and Candida albicans. False yam seed extract exhibited a higher antimicrobial activity against the microorganisms than the tuber extract, this provides a cheaper source of antimicrobial agent to treat infectious diseases.
\end{abstract}

Keywords: False yam tuber, False yam seed, Icacina oliviformis, Phytochemical screening, Minimum Inhibition Concentration (MIC), Microorganisms

\section{Introduction}

Infectious pathogens cause serious threats to humans and the environment. They are ranked as the leading cause of death worldwide and responsible for almost one-third of mortality in the torrid countries (Rahman et al., 2009). The contributing factors to the increase in infectious disease mortality rate include the recurring of diseases that were controlled before, the emergence of new diseases, and the increase in pathogenic microorganisms that are resistance to antimicrobial agents (Cohen,
2000). The most compelling contributing factor is due to the uncontrolled usage of synthetic antimicrobial agents (Abutbul et al., 2005). The increase in antimicrobial resistant pathogens have generated a lot of public health concerns and one of the proposed solutions to curb this issue is to develop new antimicrobials, a proposed solution by the Center for Disease Control, (CDC), United State of America (Fauci, 1998).

Plants with medicinal property used as a source for relief and cure of illness can 
be tracked down from the early civilization to the present times (Thomson et al., 1978). According to literature, medicinal plants form the basis of traditional medicine and that various metabolites are reserved in indigenous plants which possess an extensive source of potent compounds with numerous biotic properties (Nitta et al., 2002). Nature has endowed humankind with numerous plants with medicinal property but a lot of these plants are yet to be fully exploited. One of such medicinal plants is Icacina oliviformis (false yam plant). False yam is a small drought resistant shrubby and perennial plant which has underground fleshy tuber with erect leafy shoot (Umoh, 2013). It belongs to the family Icacinaceae and grows in the arid areas of West and Central Africa. In Ghana, it is found mainly in the Savannah, Northern, North East, Upper East and Upper West regions (Timothy et al., 2011). Icacina oliviformis is substantially use in most households in the rural communities as medicine for the treatment of diabetes, edema etc. because of its analgesic, anti-inflammatory as well as antidiabetic properties (Asuzu et al., 1999). Timothy et al. (2011) have shown that the leaves of Icacina oliviformis possess a broad antibacterial property. Nevertheless, there is insubstantial knowledge on the antimicrobial potential of false yam tuber and seed extract. Considering the potential threat of diseases associated with the use of synthetic antibiotics on human health and the environment, disease management must focus on more preventive and environmentally friendly methods such as the use of plants with antimicrobial property, which are relatively cheaper and provide greater therapeutic agents to mitigate (Punitha et al., 2008), and, if possible, curb the concomitant effects of synthetic antimicrobial. This study sought to assess the antimicrobial activity of false yam tuber and seed extracts on micro-organisms.

\section{Experimental}

False yam tubers and seeds

The false yam tubers were harvested from the soil, after which they were peeled, whereas the seeds were obtained from freshly harvested fruits that had been crushed open between December, 2017 and March, 2018. The false yam tubers and seeds were washed and the tubers cut into smaller pieces. Both samples were airdried for five days (Timothy et al., 2011).

\section{False yam tuber and seed extracts}

The dried false yam tuber and seed were pulverized in an electric mill at the Faculty of Agriculture, Kwame Nkrumah University of Science and Technology (KNUST), Kumasi Ghana. The false yam tuber and seed extract were obtained by dissolving $100 \mathrm{~g}$ of each sample in $300 \mathrm{ml}$ of $70 \%$ methanol $(\mathrm{MtOH})$ at normal room temperature for 24 hours. The samples were filtered using sterile filter papers and filtrates were placed in a hot oven at a temperature of $49^{\circ} \mathrm{C}$ for 24 hours for methanol to evaporate and gel-like extracts were obtained. The extracts were collected into sterile plastic containers and stored at room temperature for further use.

Phytochemical analysis of false yam tuber and seed extracts

Qualitative test for the presence of tannins, saponins, glycosides, alkaloids, and flavonoids were performed according to Evans (2002). No precipitate/ no color change was recorded as not present, precipitate/ color change was recorded as present, and when one precipitate/ color was more/deeper than the other, it was recorded as present and in abundance. 
Growth and maintenance of selected microorganisms for antimicrobial assay

Pure cultures of Staphylococcus aureus (ATCC 25923), Streptococcus pyogenes (Clinical strain) which are Gram-positive bacteria, Pseudomonas aeruginosa (CS/ATCC 4853), Escherichia coli (CS/ATCC 25922) which are Gram-negative bacteria and the fungus Candida albicans (Clinical strain) were obtained from the Microbiology Laboratory, KNUST. Pure cultures were pre-enriched to increase the number of microorganisms to a detectable level by placing each culture in a test tube containing $5 \mathrm{ml}$ of sterile nutrient broth and incubated for 24 hours at a temperature of $37^{\circ} \mathrm{C}$.

\section{Antimicrobial assay using agar-well diffusion} method

Two hundred milligram per milliliter $(200 \mathrm{mg} /$ ml) stock solution was prepared for each extract and concentrations of $100 \mathrm{mg} / \mathrm{ml}, 50 \mathrm{mg} /$ $\mathrm{ml}, 25 \mathrm{mg} / \mathrm{ml}$ and $12.5 \mathrm{mg} / \mathrm{ml}$ were prepared from the stock solutions. $0.1 \mathrm{ml}$ of each of the cultured microorganisms were inoculated into different sterile Petri dishes under the shield chamber. Nutrient agar was prepared by mixing $14 \mathrm{~g}$ of powdered nutrient agar (OXOID) with
$150 \mathrm{ml}$ of distilled water, brought to boil for homogeneity and sterilized by autoclaving at $121^{\circ} \mathrm{C}$ for $15 \mathrm{~min} .20 \mathrm{ml}$ of sterile nutrient agar was poured into the Petri dishes and swirled to allow uniform distribution of the microorganisms and allowed to cool for 30 minutes. A $12 \mathrm{~mm}$ diameter Cork borer was sterilized and used to bore five wells into each of the agar plates. $200 \mu \mathrm{l}$ of the false yam tuber and seed extracts in their various concentrations were aseptically pipetted into their designated agar wells. The antibiotics, Ciprofloxacin and Clotrimazole, were used as positive controls. The plates were left for 30 minutes for diffusion of the extracts into the nutrient agar and incubated at a temperature of $37^{\circ} \mathrm{C}$ for 24 hours. Plates were observed for zone of inhibition around the well. The inhibition zones were measured using a meter rule, by measuring the diameter of the wells and the surrounding clear area in millimeters. Plates with inhibition zones were considered as having antimicrobial activity whilst those without inhibition zones were considered having no antimicrobial activity. The experiment was carried out in triplicates. The various treatments were designated with codes and are shown in Table 1. Data obtained were analyzed using Genstat (Edition 12).

TABLE 1

Treatments for antimicrobial activity designated with codes

\begin{tabular}{ccc}
\hline Treatment & Concentration & Code \\
\hline Ciprofloxacin/ Clotrimazole & $50 \mu \mathrm{g} / \mathrm{ml}$ & $\mathrm{T} 1$ \\
False yam tuber extract & $100 \mathrm{mg} / \mathrm{ml}$ & $\mathrm{T} 2$ \\
False yam tuber extract & $50 \mathrm{mg} / \mathrm{ml}$ & $\mathrm{T} 3$ \\
False yam tuber extract & $25 \mathrm{mg} / \mathrm{ml}$ & $\mathrm{T} 4$ \\
False yam tuber extract & $12.5 \mathrm{mg} / \mathrm{ml}$ & $\mathrm{T} 5$ \\
False yam seed extract & $100 \mathrm{mg} / \mathrm{ml}$ & $\mathrm{T} 6$ \\
False yam seed extract & $50 \mathrm{mg} / \mathrm{ml}$ & $\mathrm{T} 7$ \\
False yam seed extract & $25 \mathrm{mg} / \mathrm{ml}$ & $\mathrm{T} 8$ \\
False yam seed extract & $12.5 \mathrm{mg} / \mathrm{ml}$ & $\mathrm{T} 9$ \\
\hline
\end{tabular}


Determination of the Minimum Inhibitory

Concentration (MIC)

Using three microtitre plates of 96 wells each, $100 \mu \mathrm{l}$ of nutrient broth was pipetted into each of the wells. $10 \mu \mathrm{l}$ of pure cultures of the various microorganisms where pipetted into designated rows on the microtitre plates to the wells on the first row, $100 \mu \mathrm{l}$ of $100 \mathrm{mg} / \mathrm{ml}$ of the extracts were pipetted into it. $100 \mu \mathrm{l}$ of $50 \mathrm{mg} / \mathrm{ml}$ was pipetted into the second row, $100 \mu \mathrm{l}$ of 25 $\mathrm{mg} / \mathrm{ml}, 12.5 \mathrm{mg} / \mathrm{ml}, 6.25 \mathrm{mg} / \mathrm{ml}, 3.125 \mathrm{mg} / \mathrm{ml}$, $1.563 \mathrm{mg} / \mathrm{ml}$ and $0.7813 \mathrm{mg} / \mathrm{ml}$ of the extracts were pipetted consecutively down the plates. Each extract was given a different plate. 100 $\mu \mathrm{l}$ of $5 \mathrm{mg} / \mathrm{ml}, 2.5 \mathrm{mg} / \mathrm{ml}, 1.25 \mathrm{mg} / \mathrm{ml}, 0.625$ $\mathrm{mg} / \mathrm{ml}, 0.3125 \mathrm{mg} / \mathrm{ml}, 0.15625 \mathrm{mg} / \mathrm{ml}, 0.0781$ $\mathrm{mg} / \mathrm{ml}$ and $0.039 \mathrm{mg} / \mathrm{ml}$ of the Ciprofloxacin and Clotrimazole were also pipetted consecutively down on a different plate. MTT dye was pipetted into all the wells and incubated for 24 hours. If the concentration of the extract was able to inhibit the growth of the microorganism, clear well will be observed but if the extract was not able to inhibit the growth of the microorganisms, there will be no color change. The minimum inhibitory concentration is the lowest concentration of the extract that inhibited or that did not show the growth of the microorganism under study.

\section{Results}

Phytochemical screening

TABLE 2

Phytochemical screening of false yam tuber and seed extracts

\begin{tabular}{lcc}
\hline Phytochemical & False yam tuber extract & False yam seed extract \\
\hline Tannins & ++ & + \\
Saponins & + & ++ \\
Glycosides & + & ++ \\
Alkaloids & ++ & + \\
Flavonoids & - & - \\
\hline
\end{tabular}

$(+)=$ present, $(-)=$ not detected, $(++)=$ present and in abundance

Phytochemical screening of both extracts indicates the presence of tannins, saponins, glycosides and alkaloids whilst flavonoids were absent in both extracts. Tannins and alkaloids were observed to be more in seed extract than tuber extract whilst glycosides and saponins were found to be more in tuber extract than seed extract (Table 2).

\section{Antimicrobial activity}

The values in Table 3 are means of the zone of inhibition $\pm 95 \%$ CI (Confidence Interval) of two independent replicates. At $\mathrm{P}<0.05$, there was significant difference between some of the treatments on the various microorganisms. 
TABLE 3

Zone of inhibition $+12 \mathrm{~mm}( \pm 95 \%$ CI) of different microbes treated with different concentration of false yam tuber and seed extracts

\begin{tabular}{|c|c|c|c|c|c|}
\hline Treatment & $\begin{array}{l}\text { Candida albi- } \\
\text { cans }\end{array}$ & $\begin{array}{l}\text { Pseudomonas } \\
\text { aeruginosa }\end{array}$ & $\begin{array}{l}\text { Streptococ- } \\
\text { cus pyogenes }\end{array}$ & $\begin{array}{l}\text { Staphylococcus } \\
\text { aureus }\end{array}$ & Escherichia colt \\
\hline $\mathrm{T} 1$ & $13.5 \pm 0.707^{\mathrm{ab}}$ & $43.25 \pm 1.061^{\mathrm{c}}$ & $27.3 \pm 0.353^{c}$ & $21.5 \pm 0.707^{d}$ & $40.5 \pm 0.707^{b}$ \\
\hline $\mathrm{T} 2$ & $13 \pm 0.000^{\mathrm{ab}}$ & $12 \pm 0.000^{\mathrm{a}}$ & $14 \pm 0.000^{\mathrm{ab}}$ & $13 \pm 0.000^{\mathrm{abc}}$ & $13 \pm 0.000^{\mathrm{abc}}$ \\
\hline $\mathrm{T} 3$ & $12.5 \pm 0.707^{\mathrm{ab}}$ & $12 \pm 0.000^{\mathrm{a}}$ & $13.5 \pm 0.707^{\mathrm{ab}}$ & $12.5 \pm 0.707^{\mathrm{ab}}$ & $12 \pm 0.000^{\mathrm{a}}$ \\
\hline $\mathrm{T} 4$ & $12 \pm 0.000^{\mathrm{a}}$ & $12 \pm 0.000^{\mathrm{a}}$ & $13 \pm 0.000^{\mathrm{ab}}$ & $12 \pm 0.000^{\mathrm{a}}$ & $12 \pm 0.000^{\mathrm{a}}$ \\
\hline T5 & $12 \pm 0.000^{\mathrm{a}}$ & $12 \pm 0.000^{\mathrm{a}}$ & $12.5 \pm 0.000^{\mathrm{a}}$ & $12 \pm 0.000^{\mathrm{a}}$ & $12 \pm 0.000^{\mathrm{a}}$ \\
\hline T6 & $15.5 \pm 0.707^{b}$ & $18.5 \pm 0.707^{\mathrm{b}}$ & $\begin{array}{l}15.5 \pm \\
0.707^{\mathrm{ab}}\end{array}$ & $15.5 \pm 0.707^{c}$ & $13 \pm 0.000^{\mathrm{a}}$ \\
\hline $\mathrm{T} 7$ & $14.5 \pm 0.707^{\mathrm{ab}}$ & $12 \pm 0.000^{\mathrm{a}}$ & $12 \pm 0.000^{\mathrm{a}}$ & $12 \pm 0.000^{\mathrm{a}}$ & $12 \pm 0.000^{\mathrm{a}}$ \\
\hline $\mathrm{T} 8$ & $14 \pm 0.000^{\mathrm{ab}}$ & $14 \pm 1.414^{\mathrm{a}}$ & $16.5 \pm 2.121^{b}$ & $15 \pm 0.000^{\mathrm{bc}}$ & $12 \pm 0.000^{\mathrm{a}}$ \\
\hline T9 & $14 \pm 1.414^{\mathrm{ab}}$ & $13 \pm 0.000^{\mathrm{a}}$ & $15 \pm 0.000^{\mathrm{ab}}$ & $14 \pm 1.414^{\mathrm{abc}}$ & $12 \pm 0.000^{\mathrm{a}}$ \\
\hline P-value & $0.006^{*}$ & $<.001^{*}$ & $<.001^{*}$ & $<.001^{*}$ & $<.001^{*}$ \\
\hline LSD $_{(0.05)}$ & 1.508 & 1.436 & 1.788 & 1.411 & 0.5332 \\
\hline CV\% & $5.0 \%$ & $3.8 \%$ & $5.1 \%$ & $4.4 \%$ & $1.5 \%$ \\
\hline
\end{tabular}

*: significant, 95\% CI :95\% confidence interval, P-value: probability value, LSD: least significant difference, $\mathrm{CV}$ : coefficient of variation.

Minimum Inhibitory Concentration (MIC)

Table 4, shows the MIC of false yam tuber and seed extract as well as the MIC for the standard drugs (Ciprofloxacin and Clotrimazole).
The MIC for the seed extract was relatively lower than the MIC for the tuber extract on the selected microorganisms.

TABLE 4

Minimum inhibitory concentration (MIC) of false yam tuber and seed extracts

\begin{tabular}{lccc}
\hline Microorganism & \multicolumn{2}{c}{ Minimum inhibitory concentration (mg/mI) } \\
$\begin{array}{c}\text { False yam tuber } \\
\text { extract }\end{array}$ & $\begin{array}{c}\text { False yam seed } \\
\text { extract }\end{array}$ & $\begin{array}{c}\text { Ciprofloxacin/ Clotri- } \\
\text { mazole }\end{array}$ \\
\hline Candida albicans & 6.25 & 1.56 & 0.078 \\
Pseudomonas aeruginosa & - & 100 & 0.078 \\
Streptococcus pyogenes & 1.56 & 1.56 & 0.078 \\
Staphylococcus aureus & 6.25 & 1.56 & 0.078 \\
Escherichia coli & 100 & 25 & 0.078 \\
\hline
\end{tabular}




\section{Discussion}

Phytochemical screening

The absence of flavonoids in both extracts as shown in Table 2 was due to the fact that flavonoids are mostly found in fruits, vegetables and beverages (Pridham, 1960). The higher proportions of tannins and alkaloids in the false yam seed extract as compared to the false yam tuber extract can be attributed to the differences in the proportion of phytochemicals present in different plant parts (Pridham, 1960).

\section{Antimicrobial activity}

From Table 3, both the false yam tuber and seed extracts had the ability to inhibit the growth of Gram-positive bacteria (Staphylococcus aureus, Streptococcus pyogenes), Gram-negative bacteria (Pseudomonas aeruginosa, Escherichia coli) and the fungus, Candida albicans. The presence of tannins, saponins, glycosides and alkaloids in both the false yam tuber and seed extracts gives the extracts the ability to inhibit growth of the microorganisms which conforms to a study by Timothy et al. (2011) who reported that the presence of phytochemicals in false yam leaves give the leaves the ability to act as an antimicrobial agent. But the mean of the zone of inhibition of the seed extract was relatively higher than that of the tuber extract at the same concentration. The higher proportions of tannins and alkaloids in the false yam seed extract may account for its higher antimicrobial activity than the false yam tuber extract (Kathad et al., 2010). This also conforms to the report by Taylor et al. (1996) which indicated that tannins present in the bark of Terminalia alata was responsible for its antimicrobial activity. Tannins form irreversible complexes with proteins of microorganisms which leads to protein inactivation and loss of function (Stern et al., 1996). Alkaloids inter- calate with DNA of foreign organisms which subsequently impede their DNA replication and transcription leading to frame-shift mutation (Jones et al., 1994). Vaghasiya and Chanda (2007) reported that, some phytochemicals become highly effective antimicrobial agents in the presence of other phytochemicals. This property of phytochemicals may be responsible for the broad-spectrum antimicrobial activity of the false yam seed extract.

\section{Minimum Inhibitory Concentration (MIC)}

Streptococcus aureus, Staphylococcus pyogenes and Candida albicans were more susceptible to the false yam seed extract with MIC of $1.56 \mathrm{mg} / \mathrm{ml}$, followed by Escherichia coli with MIC of $25 \mathrm{mg} / \mathrm{ml}$ and Pseudomonas aeruginosa being the least with MIC of 100 $\mathrm{mg} / \mathrm{ml}$. However, this is contrary to the report by Timothy \& Idu. (2011), which showed that, Pseudomonas aeruginosa and Escherichia coli were more susceptible to the methanol extract of false yam tuber and conforms to the report by Ushimaru et al. (2007) as well as that of Pavithra et al. (2010) which indicates that, the Gram-positive bacteria in this study, Streptococcus aureus and Staphylococcus pyogenes, are more susceptible to plants with antibacterial property than Gram negative bacteria (Escherichia coli and Pseudomonas aeruginosa) due to the differences in their cell wall structure, i.e., its permeability. The MIC for both extracts on the fungus, Candida albicans, and the Gram-positive bacteria (Streptococcus aureus and Staphylococcus pyogenes) was similar, this may be as a result of similarity in the permeability of their cell wall structure invaded by the extracts.

\section{Conclusion}

False yam tuber and seed extracts have shown the ability of inhibiting the growth of both 
Gram-negative and Gram-positive bacteria as well as the fungus, Candida albicans. However, false yam seed extract exhibited a relatively greater antimicrobial potential than false yam tuber extract as the MIC of seed extract on Candida albicans, Escherichia coli and Staphylococcus aureus $(1.56 \mathrm{mg} / \mathrm{ml}, 25 \mathrm{mg} / \mathrm{ml}, 1.56$ $\mathrm{mg} / \mathrm{ml}$ respectively) were relatively lower than the MIC of tuber extract on Candida albicans, Escherichia coli and Staphylococcus aureus $(6.25 \mathrm{mg} / \mathrm{ml}, 100 \mathrm{mg} / \mathrm{ml}$ and $6.25 \mathrm{mg} /$ $\mathrm{ml}$ ). This suggests that, false yam seed possess broad spectrum antimicrobial potential, which may be a source of new antimicrobials to treat infectious diseases and also provide a cheaper source of treatment with higher accuracy and curb the side effects associated with synthetic antimicrobials. False yam seed extract also competed favorably with the standard drugs, the active ingredients (phytochemicals) present in the false yam seed extract should be isolated, purified and utilized for the development of new antimicrobials for the treatments of infectious diseases.

\section{Acknowledgements}

We thank the entire lecturers of the Department of Biotechnology, University for Development Studies, Tamale, Ghana, for their immense support towards the success of this research. We also thank Mr. Yagle Isaac, Mr. Alidu Abdul Hafiz and Mr. Amankwa Francis for their editing and technical support. Our greatest gratitude to Mr. Munkaila G. Mohammed and our entire families for their prayers, love and financial support.

\section{References}

Abutbul, S., Golan-Goldhirsh, A., Barazani, O., Ofir, R. \& ZilberG, D. (2005) Screening of desert plants for use against bacterial pathogens in fish. Israeli Journal of Aquaculture-BAMIGDEH 57 (2), 71 - 80.

Asuzu, I. U., Sosa, S. \& Della Loggia, R. (1999) The antiinflammatory activity of Icacina trichantha tuber. Phytomedicine 6 (4), 267 - 272.

Cohen, M. L. (2000) Changing patterns of infectious disease. Nature 406 (6797), 762.

Evans, W. C. (2002) Trease and Evans pharmacognosy. Bailliere Tindall: London.

Fauci, A. S. (1998) New and reemerging diseases: the importance of biomedical research. Emerging Infectious Diseases 4 (3), 374.

Jones G. A., Mc Allister, T. A. \& Muir, A. D. (1994) Effects of Sainfoin (Onobrychis vicifolia scop.) condensed tannins on growth and proteolysis by four strains of ruminal bacteria. Applied Environmental Microbiology 60, 1374 - 1378.

Kathad, H. K., Shah, R. M., Sheth N. R. \& Patel, K. N. (2010) In vitro antioxidant activity of leaves of Garuga pinnata Roxb. International Journal of Pharmaceutical Research 2 (3), 9-13.

Nitta, T., Arai, T., Takamatsu, H., Inatomi, Y., MuraTA, H., InUma, M. \& IBRahim, I. (2002) Antibacterial activity of extracts prepared from tropical and subtropical plants on methicillin-resistant Staphylococcus aureus. Journal of Health Science 48 (3), $273-276$.

Pavithra, P. S., Janani, V. S., Charumathi, K. H., InDumathy, R., Srisha, P. \& Rama, S. V. (2010) Antibacterial activity of plants used in Indian herbal medicine. International Journal of Green Pharmacy 4 (1), 22 - 28.

Pridham, J. B. (1960) Phenolics in plants in health and disease. Pergamon Press, New York. pp. $34-35$. 
Punitha, S. M. J., Babu, M. M., Sivaram, V., Shankar, V. S., Dhas, S. A., Mahesh, T. C. \& Citarasu, T. (2008) Immunostimulating influence of herbal biomedicines on nonspecific immunity in Grouper Epinephelus tauvina juvenile against Vibrio harveyi infection. Aquaculture International 16 (6), $511-523$.

Rahman, F., Chowdhury, S., Rahman, M. M., Ahmed, D. \& Hossain, A. (2009) Antimicrobial resistance pattern of Gram-negative bacteria causing urinary tract infection. Stamford Journal of Pharmaceutical Sciences 2 (1), 44 - 50.

Stern J. L., Hagarman A. E., Steinberg P. D. \& MaSON, P. K. (1996) Phlorotannin- protein interactions. Journal of Chemical Ecology 22, 1887 $-1899$.

TAYlor R. S. L. \& Edelf, M. N. P. (1996) Antimicrobial activities of southern Nepalese medicinal plants. Journal of Ethnopharmacology 50, 97 -102 .
Thomson, W. A. R. \& Schultes, R. E. (1978) Medicines from the Earth. McGraw-Hill Book Co., Maidenhead, United Kingdom.

Tімотну, O. \& Idu, M. (2011) Preliminary phytochemistry and in vitro antimicrobial properties of aqueous and methanol extracts of Icacina trichantha Oliv. Leaf. International Journal of Medicinal and Aromatic Plants 1 (3), 184 188.

Uмон, E. O. (2013) Anti nutritional factors of false yam (Icacina tricachantha) flour. Internet Journal of Food Safet, 15, $78-82$.

Vaghasiya, Y. \& Chanda, V. S. (2007) Screening of methanol and acetone extracts of 14 Indian medicinal plants for antimicrobial activity. Turkish Journal of Biology 31, 243 - 248.

Received 27 Jun 19; revised 30 Aug 19. 